Teresa WEASOW

Hematology

\title{
ERYTHROCYTE SYSTEM OF RAINBOW TROUT, SALMO GAIRDNERI RICH. AFFECTED BY PROLONGED SUBACUTE PHENOL INTOXICATION
}

UKLAD CZERWONOKRWINKOWY PSTRĄGA TEZCZOWEGO SALMO GAIRDNERI RICH. W PRZEDLUŻONEJ PODOSTREJ INTOKSYKACJI FENOLOWEJ

\author{
Department of Fisheries \\ Faculty of Water Protection \\ and Inland Fisheries Academy \\ of Agriculture and Technology, \\ Olsztyn
}

\begin{abstract}
Basic erythrocyte indices, ery throcyte osmotic resistance as well as quantitative and qualitative analysis of the erythrocyte pattern in the peripheral blood, spleen and kidney of rainbow trout affected by phenol intoxication ( $2 \mathrm{mg} \mathrm{dm}{ }^{-3}$ doses applied for 2 months in winter) are presented.
\end{abstract}

\section{INTRODUCTION}

Phenol although present in water bodies in concentrations lower than lethal, is rather common. Dougharty (in Metelev et al., 1971) has regarded the compound as a strong toxin. It brings about a general intoxication with no specific symptoms; its action is both local - corrosive or irritating, depending on concentration - and systemic (ReichenbachKlinke, 1965; Waluga, 1975). The coumpound causes the fish nerval system disfunction (Flerow, 1970; Gdovskij et al., 1974; Lukjanenko, 1974). By damaging blood cells it 
affects the abundance of various types of blood cells (Halsband and Halsband, 1963; Waluga, 1975; W łasow, 1980).

In the course of chronic phenol intoxication in fish, juvenile erythrocytes in the peripheral blood were found to occur in increased abundance (Waluga, 1975), which points out to intensified erythropoiesis in phenol-intoxicated fish. In the present work, the rainbow trout erythrocyte pattern was studied in order to find out if prolonged subacute intoxication results in impaired or intensified erythropoiesis.

\section{MATERIALS AND METHODS}

The materials studied consisted of 196 rainbow trout: (Salmo gairdneri Rich.) individuals aged 1+. The fish originated from the Szwaderki Fish Farm and were in good condition. The mean length and weight were $22.6 \mathrm{~cm}\left(\mathrm{~s}_{\mathrm{x}}=1.9 \mathrm{~cm}\right)$ and $123.4 \mathrm{~g}$ $\left(s_{x}=30.4 \mathrm{~g}\right)$, respectively.

Pure grade phenol produced by the Oświęcim Chemical Plants was used in the experiments.

The experiments were carried out in $250 \mathrm{dm}^{3}$ aquaria fed with aerated lake water (Table 1). Water aeration, temperature, and $\mathrm{pH}$ were checked daily; the results of measurements are presented in Table 2.

Based on preliminary tests, the phenol concentration and exposition were set at $2 \mathrm{mg}$ $\mathrm{dm}^{-3}$ and 2 months, respectively. The experimental solution was obtained by diluting the fresh stock solution; it was changed daily. The experiment was carried out in winter (December 1978 - February 1979) as the rainbow trout is then more resistant to phenol (Własow, 1980) and a more pronounced response from the hemopoietic system can be expected.

The rainbow trout were adapted to conditions in the aquaria for 2 weeks. The experimental and control groups consisted of 112 and 84 individuals, respectively, 14 individuals per aquarium. The fish were fed with pelleted food.

On the outset of the experiment, blood for hematologic assays was collected from the heart. Also the hemopoietic organs: spleen and kidney, were examined. The following assays were performed: erythrocyte count and hemoglobin content, by means of procedures generally applied in fish studies (Klontz and Smith, 1968; Blaxhall and Daisley, 1973); hematocrit (relative erythrocyte volume), by micromethod in heparin capillaries (Krawczyński and Osiński, 1967); mean hemoglobin content (MCH), mean corpuscles hemoglobin content (MCHC), and mean cell volume (MCV), calculated with Wintrobe's formulae (Krawczyński and Osiński, 1967).

Erythrocyte osmotic resistance was determined by acidic erythrograms modified for fish (Telitchenko and Govorova, 1962) in a Specol $(\lambda=580 \mathrm{~nm})$. The osmotic resistance index was calculated according to Terskov and Gitelzon (1957).

The erythrocytes were examined in panchromatically stained (Pappenheim's MGG technique) smears. Percentages of various blood cells in the spleen and kidney were 
Chemical characteristics of the water used in experiment

\begin{tabular}{|c|c|c|c|c|c|c|c|c|c|c|c|c|c|}
\hline $\mathrm{N}_{\mathrm{NH}_{4}}$ & $\mathrm{~N}_{\mathrm{NO}_{2}}$ & $\mathrm{~N}_{\mathrm{NO}_{3}}$ & $\mathrm{Fe}_{\text {tot. }}$ & $\mathrm{SiO}_{2}$ & $\mathrm{P}_{\mathrm{PO}_{4}}$ & $\mathrm{Cl}$ & $\mathrm{SO}_{4}$ & $\mathrm{CO}_{3}$ & $\mathrm{HCO}_{3}$ & $\mathrm{Ca}$ & $\mathrm{K}$ & $\mathrm{Na}$ & Oxidability \\
\hline & \multicolumn{12}{|c|}{$\mathrm{mg} / \mathrm{dm}^{3}$} & $\mathrm{mg} \mathrm{O}_{2} / \mathrm{dm}^{3}$ \\
\hline 0.12 & 0.016 & 0.54 & 0.29 & 24.5 & 0.061 & 12.2 & 9.7 & 0.0 & 219 & 49 & 3.1 & 9.3 & 10.6 \\
\hline
\end{tabular}

Table 2

Oxygen content, temperature and $\mathrm{pH}$ of the water

\begin{tabular}{|c|c|c|c|c|c|c|}
\hline \multirow[t]{2}{*}{ Groups } & \multicolumn{2}{|c|}{$\begin{array}{l}\text { Oxygen content } \\
\mathrm{mgO}_{2} / \mathrm{dm}^{3}\end{array}$} & \multicolumn{2}{|c|}{$\begin{array}{c}\text { Water temperature } \\
{ }^{\circ} \mathrm{C}\end{array}$} & \multicolumn{2}{|c|}{ Water $\mathrm{pH}$} \\
\hline & RANGE & MEAN & RANGE & MEAN & RANGE & MEAN \\
\hline Exp. & $5.4-10.8$ & 8.3 & $6.0-14.5$ & 9.3 & $7.2-7.6$ & 7.4 \\
\hline Control & $6.8-9.6$ & 7.8 & $6.0-14.5$ & 9.5 & $7.3-7.6$ & 7.5 \\
\hline
\end{tabular}


determined from prints stained as the smears. When calculating the per cent composition of blood cells in the spleen and kidney, 500-800 cells were examined, as in mammalians myelo- and splenograms (Barański et al., 1962).

The results were treated statistically by means of analysis of variance with Fisher's F test.

\section{RESULTS}

\section{Peripheral blood}

The erythrocyte count in the experimental fish averaged $1.05 \times 10^{6} \mathrm{~mm}^{-3}$, which is by $5.4 \%$ lower than the average in the control (Table 3), the difference being statistically non-significant. On the other hand, the erythroblast proportion in the experimental fish peripheral blood was decidedly higher (11.5\%) than that in the control (3.3\%).

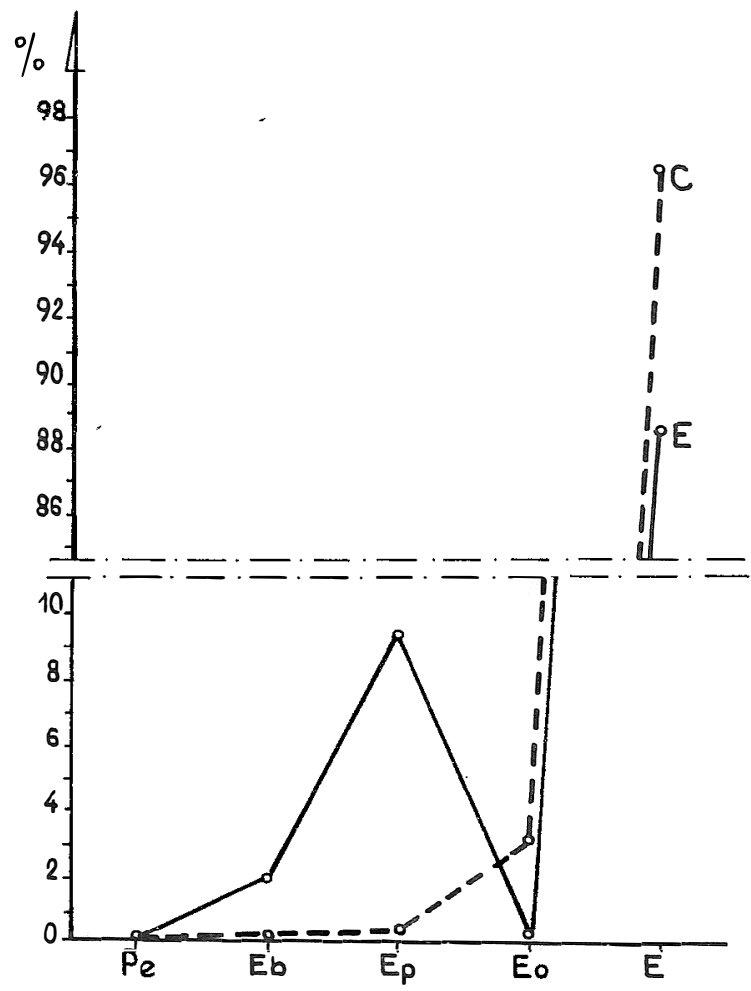

Fig. 1. The blood. Red blood cells maturity of rainbow trout (S. gairdneri Rich.) after 2 - month exposure to $2 \mathrm{mg} / \mathrm{dm}^{3}$ of phenol. $\mathrm{E}$ - experimental, C - control. Pe - proerythroblasts, $\mathrm{Eb}$ - basoph. erythroblasts, Ep - polichromatophilic erythroblasts, Eo - orthochœrythroblasts, E - erythrocytes. 
The predomination of juvenile erythrocytes evidences an intensified erythropoiesis.In the phenol-exposed rainbow trout the erythrocyte renewal was disturbed both quantitatively and qualitatively. The peripheral blood showed an out-of-proportion increase in the polychromatic erythroblasts and a decrease in ortochromatic erythroblasts (Fig. 1).

The erythrocytes occurring in the experimental fish blood were of different size (anisocy tosis) and varied in shape (poikilocytosis) (Fig. 2). The cells underwent structural alterations resulting from degenerative changes. Cytoplasm was unevenly thickened (Fig. 3), with basophil granulations (Fig. 4), the nucleus frequently transferred to the cell

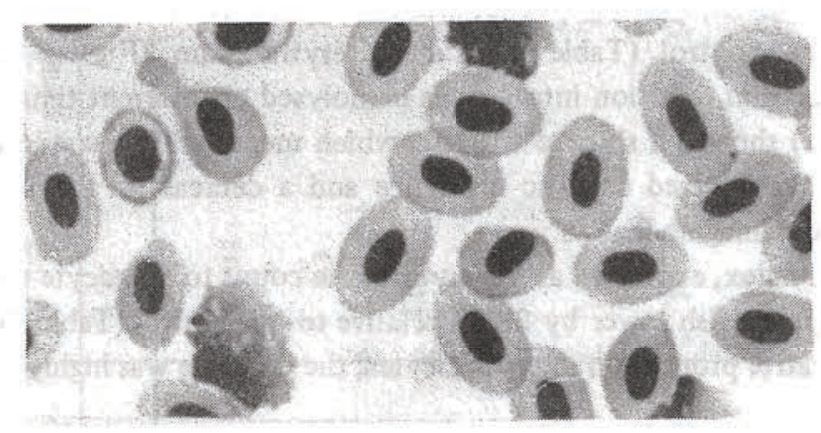

Fig. 2. The blood. Anisocytosis, poikilocytosis, erythrocytic shadows. MGG. x 1250

Phot. C. Nagięć

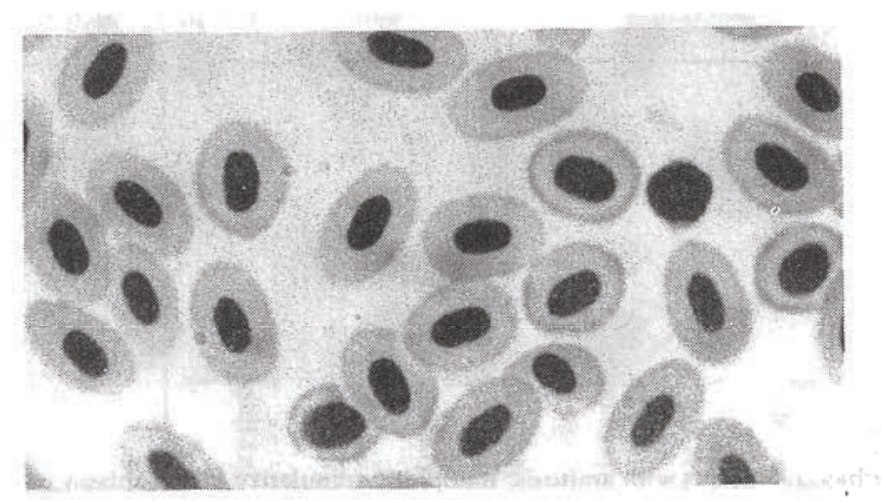

Fig. 3. The blood. Structural changes in cytoplasm of red blood cells. MGG.x1250

Phot. C. Nagięć 
margin (Fig. 2). Nuclei of altered erythroblasts and erythrocytes had thinned chromatin with a clear separation of basochromatin strands. That was a rather common process, although not a very intensive one. More rare were nuclei in the amitotic division, narrowed or segmented (Fig. 4). The phenol-exposed fish blood more frequently contained pre-hemolytic spherocy tes and cellular shadows (Fig. 2).

The relative ery throcy te volume (hematocrit) of the experimental fish was $35.9 \%$, i.e., by $11.6 \%$ lower than that of the control fish.

The hemoglobin concentration in the experimental fish was also significantly lower (by 13\%) relative to the control (Table 3). Similarly, the mean cell hemoglobin content $(\mathrm{MCH})$ decreased by $8.9 \%$ relative to the control. On the other hand, the mean corpuscle hemoglobin content (MCHC) and the mean erythrocyte volume (MCV) of the experimental fish showed no significant differences with the control values (Table 3).

The osmotic resistance of the phenol-intoxicated fish erythrocytes was by $7 \%$ lower than that in the control (Table 3). A mean erythrogram (Fig.5) illustrating the erythrocyte population partition into groups hemolysed at different time (thus differing in their resistance) showed a shift to the left, which means an increase in the amount of erythrocytes with a lowered osmotic resistance and a decrease in the amount of those highly resistant to damaging factors.

The blood cell index, expressed as the ery throcyte count to leukocyte count ratio, was in the phenol-exposed fish lower by $28.3 \%$ relative to the control (Table 3), pointing out to a decreased relative proportion of ery throcytes; the decrease was highly significant.

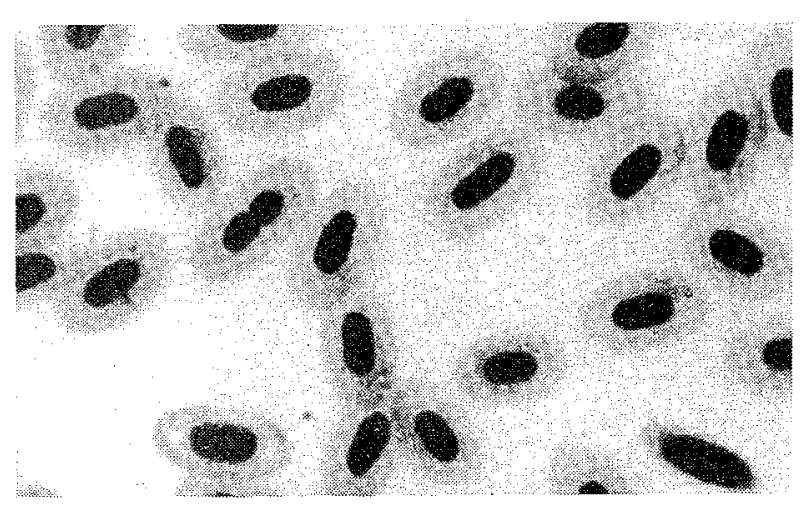

Fig. 4. The blood. Nucleus with amitosis. Basophilic granularity in cytoplasm of ery throcytes MGG. $x 1250$ 
Haematological indices of rainbow trout (S. gaird neri Rich.) after 2 -month exposure to $2 \mathrm{mg} / \mathrm{dm}^{3}$ of phenol

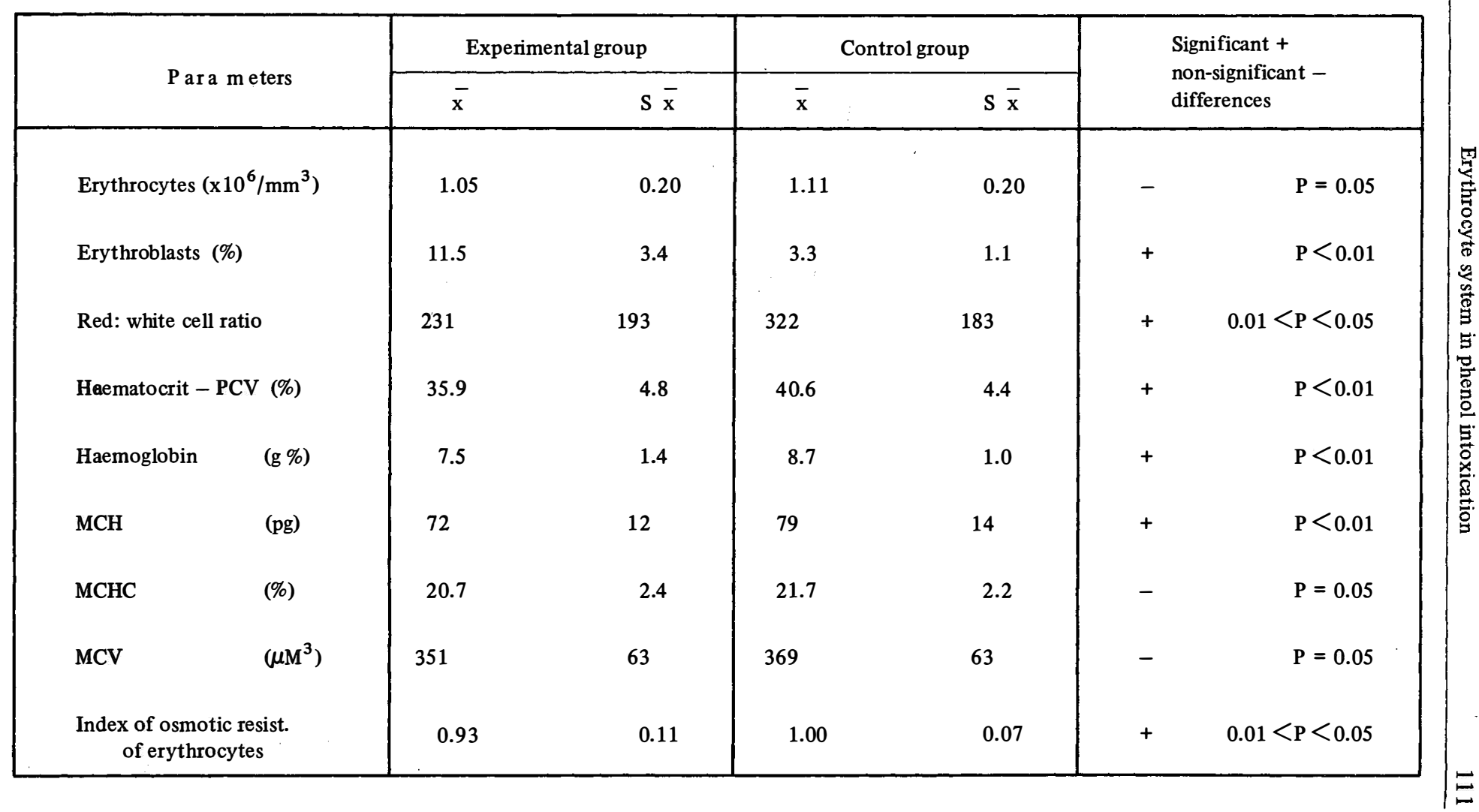




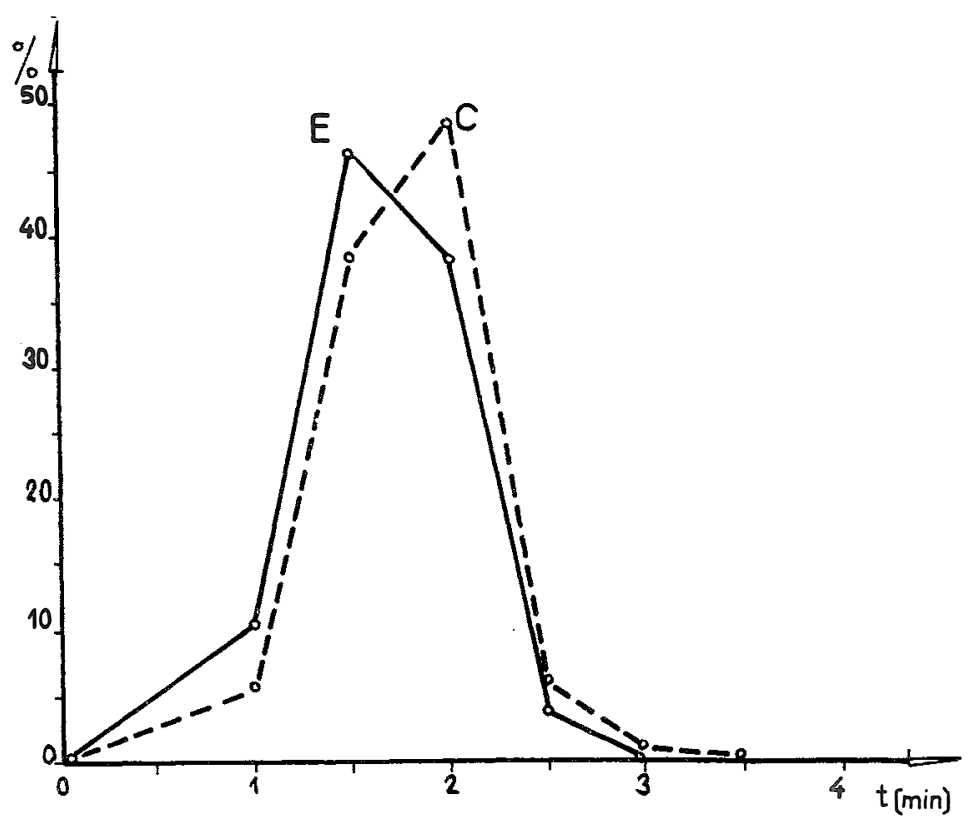

Fig. 5. Acidic erythrogramme of erythrocyte resistance of rainbow trout (S. gairdneri Rich.) after 2 month exposure to $2 \mathrm{mg} / \mathrm{dm}^{3}$ of phenol. $\mathrm{E}$ - experimental, C - control, $\mathrm{t}$ - time, \% - of haemolysed erythrocytes

\section{HEMOPOIETIC ORGANS}

The spleen of the experimental fish showed the same proportion of proerythroblasts as that in the control (Table 4), the proportion of basophil erythroblasts being markedly higher (by 17\%) than that in the control. The differences between the experimental and control fish in poly- and ortochromatic erythroblasts were non-significant.

The erythrocyte system maturity curve (Fig.6) in the spleen of the intoxicated fish confirms the presence of intensified erythropoiesis with respect to basophil ery throblasts. This phenomenon can be accounted for by an intensified erythroblast amitosis accompanying mitotic divisions. However, apart from intensified erythropoiesis, the organ showed degenerative changes which resulted in the emergence of paraerythroblasts, atypical cells with narrowed parts and projections. Some of them were unusually large ellipsoid in shape, with obliterated margins. Paraerythroblast nuclei were atypical, of ten pear-shaped or excessively elongated (Fig. 7). Numerous erythroblasts showed a differential maturation of nuclei and cytoplasm, the nuclei being more mature than the cytoplasm.

In the kidney of the phenol-exposed fish, the proportion of paraerythroblasts decreased by $38.5 \%$ as compared with the control, the decrease being statistically significant (Table 4). No difference in basophil erythroblasts between the experimental and control fish was recorded. On the other hand, the proportion of polychromatic 
Red blood cells in the spleen and kidney of rainbow trout (S. gairdneri Rich.) after 2-month exposure to $2 \mathrm{mg} / \mathrm{dm}^{3}$ of phenol.

(In percentage of all cells)

\begin{tabular}{|c|c|c|c|c|c|c|}
\hline \multirow{3}{*}{$\begin{array}{c}\text { Cells } \\
\text { in the spleen: } \\
\text { proerythroblasts }\end{array}$} & \multicolumn{2}{|c|}{ Experimental group } & \multicolumn{2}{|c|}{ Control group } & \multirow{2}{*}{\multicolumn{2}{|c|}{$\begin{array}{l}\text { Significant }+ \\
\text { non-significant }- \\
\text { differences }\end{array}$}} \\
\hline & $\bar{x}$ & $\overline{s_{x}}$ & $\overline{\mathrm{x}}$ & $s \bar{x}$ & & \\
\hline & 0.1 & 0.2 & 0.1 & 0.2 & - & $P=0.05$ \\
\hline alkal. erythrobl. & 4.4 & 2.2 & 1.6 & 1.7 & + & $\mathrm{P}<0.01$ \\
\hline polychr. erythrobl. & 4.3 & 2.3 & 5.0 & 3.5 & - & $P=0.05$ \\
\hline orthochr. erythrobl. & 1.1 & 0.8 & 1.5 & 1.7 & - & $P=0.05$ \\
\hline erythrocytes & 21.7 & 8.3 & 24.9 & 8.2 & - & $P=0.05$ \\
\hline \multicolumn{7}{|l|}{ in the kidney: } \\
\hline proerythroblasts & 1.6 & 1.5 & 2.6 & 1.5 & \multicolumn{2}{|c|}{$+0.01<\mathrm{P}<0.05$} \\
\hline alkal. erythrobl. & 4.4 & 3.1 & 4.0 & 2.5 & - & $P=0.05$ \\
\hline polychr. erythrobl. & 4.6 & 3.0 & 6.8 & 4.7 & & $<P<0.05$ \\
\hline orthochr. erythrobl. & 2.7 & 1.8 & 1.8 & 0.7 & & $<P<0.05$ \\
\hline erythrocytes & 7.0 & 6.4 & 8.5 & 5.1 & - & $P=0.05$ \\
\hline
\end{tabular}

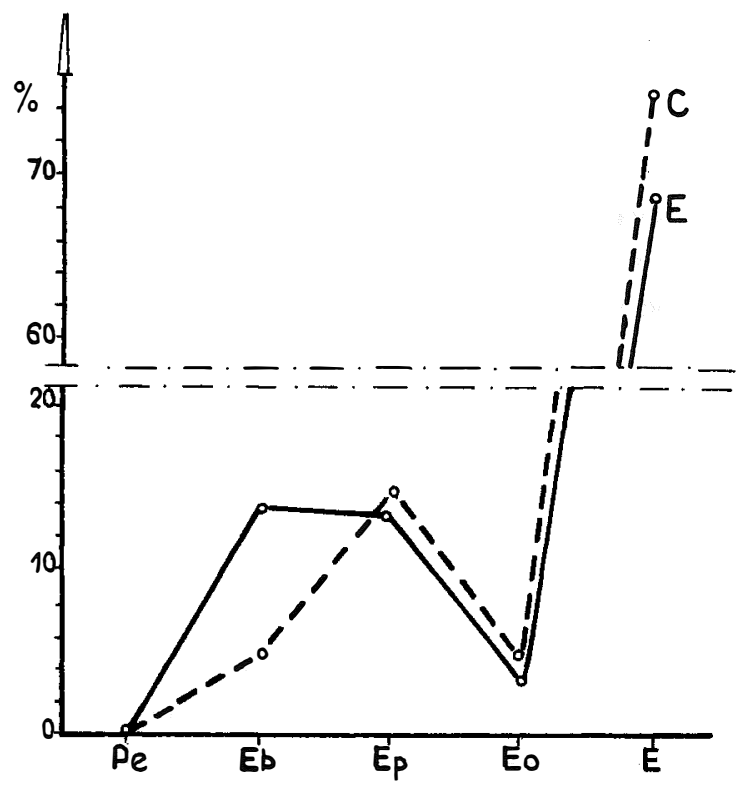

Fig. 6. The spleen. Red blood cells maturity of rainbow trout (S. gairdneri Rich.) after 2 - month Symbols used as in fig. 1 . exposure to $2 \mathrm{mg} / \mathrm{dm}^{3}$ of phenol. E - experimental, C - control. 


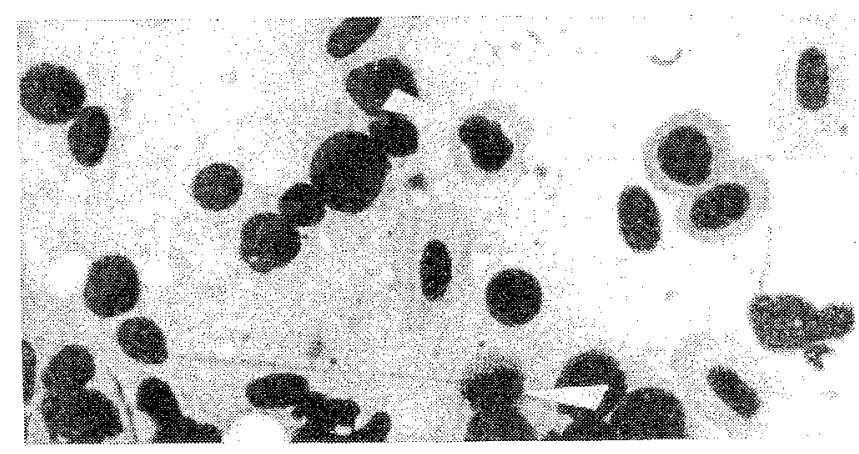

Fig. 7. The spleen. Paraerythroblastes with irregular nucleus. MGG. x 1250.

Phot. C. Nagięć

erythroblasts decreased by $32.4 \%$ in the intoxicated fish. Apart from a retarded erythropoiesis in the kidney with respect to proerythroblasts and polychromatic erythroblasts, the experimental fish showed a $50 \%$ increase in ortochromatic erythroblasts as compared to the control. The erythrocyte system maturity curve was irregular (Fig. 8), evidencing a deficit of maternal cells and polychromatic erythroblasts.

The erythrocyte pattern showed the presence of paraerythroblasts, as was the case in the experimental individuals spleen. Both these cells and erythroblasts showed unevenly thickened cytoplasm and displaced nucleus (Fig. 9). Moreover, vacuolar degeneration of the cytoplasm and nucleus was much more pronounced than in the spleen (Figs. 9, 10). A considerable amount of cells in mitosis showed lytic changes (Fig. 10).

\section{DISCUSSION}

The erythrocyte system of the rainbow trout subject to prolonged subacute intoxication showed a number of alterations of varying directions and intensity. Some of those alterations, such as the peripheral blood erythroblastosis or a strong increase in basophil erythroblast proportion in the spleen indicate an intensified erythropoiesis in organisms exposed to phenol. Such a non-specific reaction as the blood erythroblastosis was observed in phenol intoxications of bream (Waluga, 1966, 1975) and other species (Metelev et al., 1971). However, the kidney which is the main blood-producing organ in the rainbow trout (Fijan, 1961; Klontz, 1972; Ostroumova, 1957), showed a retarded erythropoiesis, particularly with respect to proerythroblasts;, a stage very important for the process. 


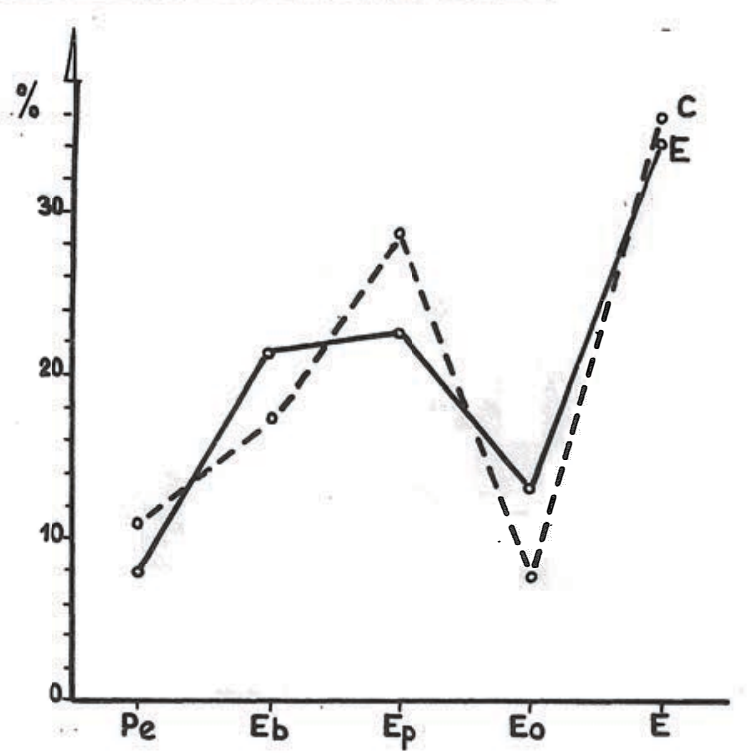

Fig. 8. The kidney. Red blood cells maturity of rainbow trout (S. gairdneri Rich.) after 2 - month exposure to $2 \mathrm{mg} / \mathrm{dm}^{3}$ of phenol. E - experimental, C - control.

Symbols used as in fig. 1 .

Apart from a deficit in maternal red cells .. in that organ, a significant reduction in polychromatic erythroblasts was observed, which generally gives a negative prognosis with respect to erythropoiesis in the phenol-exposed rainbow trout.

The kidney erythropoietic function, presumably impaired by phenol, was intercepted by the spleen which showed intensified erythropoiesis. This phenomenon confirms the hemopoietic function replacement between these two organs (Fijan, 1971). However, one should consider the spleen erythropoietic capacity in view of the blood-destroying processes operative in the blood itself and in the blood-producing organs. The processes were evidenced by more numerous spherocytes and cellular shadows in the experimental fish as well as by the decreased erythrocyte osmotic resistance typical of spherocytosis (Ławkowicz and Krzemińska-Ławkowiczowa, 1973).

A reduced erythrocyte osmotic resistance was observed in the rainbow trout exposed to sublethal and lethal phenol concentrations (Własow, 1980) and also in the fish exposed to radioactivity (Telitchenko and Govorova, 1962). The reduction of this parameter means an elevated susceptibility of the cells to hemolytic agents as well as changed physical and chemical structures of cell membranes.

Additionally morphotic (aniso-, poikilo-, and schizocytosis) and structural (degeneration and necrobiosis) changes were observed in the blood and in the hemopoietic organs. Those changes were more intense in the kidney, which would explain the retarded erythropoiesis in the organ.

The blood-destroying effects of phenol are further evidenced, apart from morphotic 

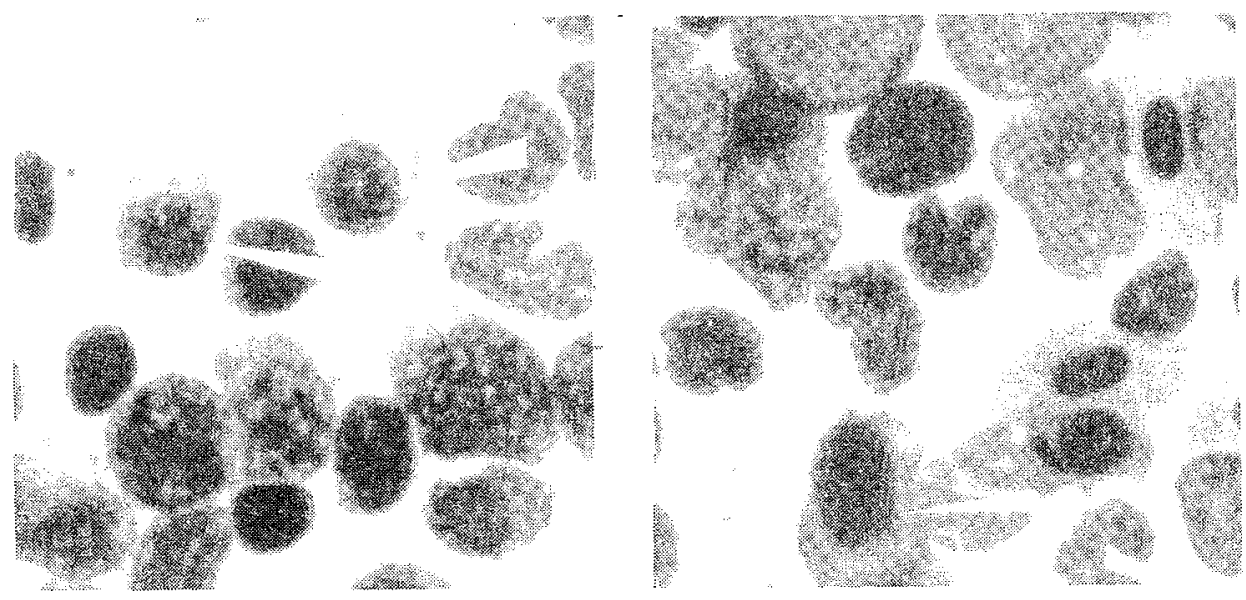

Fig. 9. The kidney. Paraerythroblastes with untypical intracellular structure. Note dyslocated nuclei. MGG. x 1250.

Phot. C. Nagięć

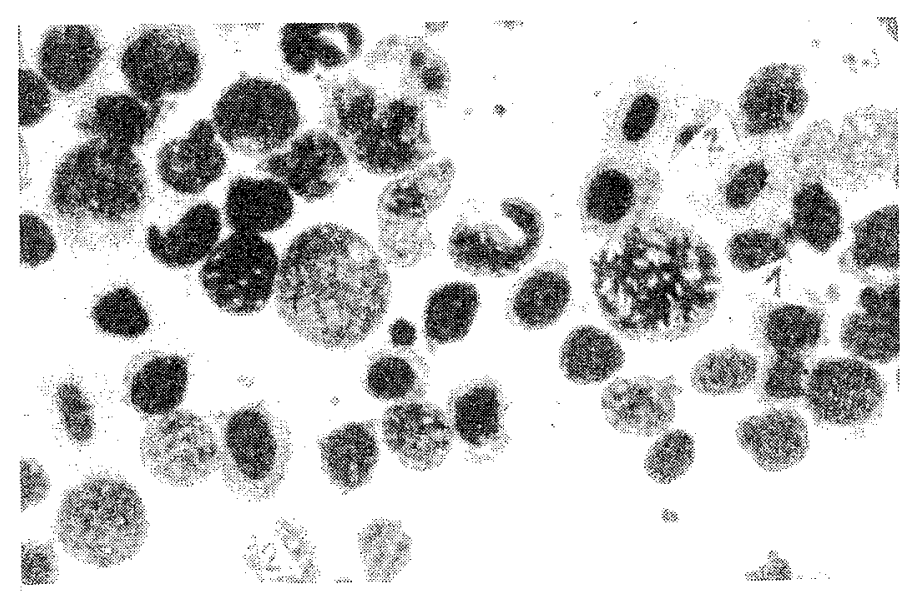

Fig. 10. The kidney. Lytic changes in mitotic stage of erythroblast. Vacuole degeneration in cytoplasm (1). Paraery throblastes (2). MGG. $x 1250$

Phot. C. Nagięć

changes and reduced erythrocyte osmotic resistance, by the decreased hematocrit, hemoglobin content, and mean cell hemoglobin content. The decreased hematocrit in the experimental fish blood was a symptom of a decreased erythrocyte volume. Other workers not always were able to give unambiguous data with respect to that parameter. Swift (1978) reported no change in hematocrit of phenolexposed rainbow trout; on the other hand, Halsband and Halsband (1963) when workin with similar phenol concentrations, recorded a $12 \%$ increase. Similarly, an unchanged hematocrit was observed in 
pike subject to subacute concentrations (McKim et al., 1976). Thus the parameter discussed should be treated with caution, the more so that, as stated by some authors (Barański et al., 1962), its diagnostic value refers to a non-differentiated ery throcyte population only.

Among various hematologic parameters studied, the erythrocyte index was decreased in the experimental fish, which points out to a reduced proportion of erythrocytes relative to leukocytes. The role of leukocytes in the prolonged subacute phenol intoxication of the rainbow trout is discussed elsewhere (Własow, in press).

\section{CONCLUSIONS}

1. Erythroblastosis occuring in the blood of the rainbow trout affected by prolonged phenol intoxication does not evidence intensified erythropoiesis. Similarly, the increase in basophil ery throblasts in the spleen is no proof of intensified ery thropoiesis in view of:

- strongly retarded erythropoiesis at the basic stage in the kidney, the principal hemopoietic organ of the rainbow trout,

- The presence of hypobiotic changes in erythrocytes of the peripheral blood and hemopietic organs, the kidney in particular.

2. In spite of a compensatory reaction, the erythrocyte system can be regarded as impaired and giving no favourable prognosis.

\section{REFERENCES}

Barański, S., P. Czerski, I. Krzemińska-Ławkowicz, T. Krzymowski, W. Ławkowicz, 1962: Układ krwiotwórczy zwierząt laboratoryjnych. [Hematoietic system of laboratory animals]. PWN, Warszawa.

Blaxhall, P.C., Kw. Daisley, 1973: Routine haematological methods use with fish blood, - J. Fish. Biol., 5: 771-781.

Fijan, N., 1961: Hemopoetska funkcija bubrega nekih vrsta slatkovodnih riba, - Bioloŝki glasnik, 14: 167-216. (in Yugoslovian).

Flerov, B.A., 1970: Issledovaniya khronicheskoy fenoloy intoksykacyi Lebistes reticulatus P. In: Voprosy vodnoy toksikologii. Nauka, Moskva: 163-168. (in Russian).

Gdovskiy, P.A., G.I. Flerova, B.A. Flerov, 1974: O vliyanii fenola na nervnuyu sistemu i nervnomyshechnoye soyedineniye nisshikh pozvonochnykh, -Biol. Vnutr. Vod., 22: 44-47. (in Russian).

Halsband, E., J. Halsband, 1963: Veränderungen des Blutbildes von Fischen infolge toxischer Schäden,- Arch. Fischereiwiss., 14, 1/2: 68-85.

Klontz, G.W., 1972: Haematological techniques and immune response in rainbow trout, - Symp. Zool. Soc. Lond., No. 30: 89-99.

Klontz, G.W., L.S. Smith, 1968: Methods of using fish as biological research subjects. In: W.I. Gay (ed.), Methods of animal experimentation, vol. III. Academic Press, New York - London, pp. 353-355. 
Krawczyński, J., T. Osiński, 1967: Laboraturyjne metody diagnostyczne, [Laboratory diagnostic method]. PZWL, Warszawa.

Ławkowicz, W.,I. Krzemińska-Ław kowiczowa,1973: Kliniczna diagnostyka różnicowa w hematologii. [Differential clinical diagnostics in hematology]: PZWL Warszawa.

Łukjanienko, W.r., 1974: Tok sykologia ryb. [Fish toxicology]. PWRiL, Warszawa.

Mc Kim, J.M., R.L. Anderson, D.A. Benoit, R.L. Spehar, G.N. Stokes, 1976: Effects of pollution on freshwater fish - Journal WPCF, 6 (48): 1544-1620.

Metelev, W.W., A.J. Kanayev, N.G. Dhasokhova, 1971: Vodnaya toksikologiya, Kolos, Moskva. (in Russian),

Ostroumova, I.N., 1957: Pokazateli krovi i krovetvoreniye v ontogeneze ryb, - Izv. WNIOHRK, 43, 3: 3-64 (in Russian).

Reichenbach-Klinke, H.H., 1965: Der Phenologehalt des Wassers in seiner Auswirkung auf den Fischorganismus, - Arch. Fischereiwiss., 16, 1: 1-16.

Stankiewicz,W., 1973: Hematologia weterynaryjna. [Veterinary hematology]. PWRiL, Warszawa.

Swift ,D.J., 1978: Some effects of exposing rainbow trout (Salmo gairdneri Rich.) to phenol solutions, - J. Fish Biol., 13, 1: 7-17.

Telitchenko, M.M., M.F. Govorova, 1962: Rannaya diagnostika toksikozov ryb metodom erytrogramm. - Vopr. ikhthyol., 3, 24: 393-396. (in Russian).

Terskov, I.A., I.I. Gitelzon, 1957: Metod khimicheskikh (kislotnykh) erytrogramm - Biofizika, 2, 2: 259-266. (in Russian).

Waluga, D.,. 1966: Phenol induced changes in the peripheral blood of the breams Abramis brama (L.), - Acta Hydrobiol., 8, 2: 87-95.

Waluga, D., 1975: Wpływ długotrwałego oddziaływania fenolu w niskiej koncentracji na leszcza Abramis brama (L.) [Effects of long-term exposure to low phenol concentrations on bream, Abramis brama (L.) ]. - Zesz. nauk. ART Olsztyn, 4: 35-78.

Własow,T., 1980: Wpływ fenolu na krew pstragga tęczowego (Salmo gairdneri Rich.) z uwzględnieniem sezonowości. [Effects of phenol on blood of rainbow trout (Salmo gairdneri Rich.), with a reference to seasonality]. - Zesz. nauk. ART Olsztyn, 11: 67-74.

Własow, T.,, Układ białokrwinkowy pstraga tęczowego Salmo gairdneri Rich. w przedłużonej podostrej intoksykacji fenolowej [praca przygotowywana do druku w Acta ichthyol. et piscat.] (Leukocyte system of rainbow trout Salmo gairdneri Rich. in prolonged sub-acute phenol intoxication (paper submitted for Publication in AIP).

Translated: Dr. Teresa Radziejewska

Teresa W łasow

\section{UKŁAD CZERWONOKRWINKOWY PSTRĄGA TECCZOWEGO SALMO GAIRDNERI RICH. W PRZEDŁUŻONEJ PODOSTREJ INTOKSYKACJI FENOLOWEJ}

\section{STRESZCZENIE}

Badano układ czerwonokrwinkowy pstrąga tęczowego (196 szt.) poddanego działaniu fenolu $\left(2 \mathrm{mg} / \mathrm{dm}^{3} 2\right.$ miesiące).

Stwierdzono obniżenie $\mathrm{Ht}$, stężenia hemoglobiny $(\mathrm{Hb})$ w krwi i $\mathrm{MCH}$ oraz spadek oporności osmotycznej erytrocytów przy zachowaniu liczby erytrocytów, ich średniej objętości (MCV) i średniego stężenia $\mathrm{Hb}$ w krwince (MCHC). 
Analiza ilościowa komórek badanego układu wykazała statystycznie istotną ery troblastozę w krwi obwodowej, zahamowabie erytropoezy na szczeblu proerytroblastów w nerce i nieproporcjonalny wzrost udziału erytroblastów zasadochłonnych w śledzionie.

W komórkach układu czerwonokrwinkowego stwierdzono szereg zmian morfotycznych i strukturalnych wynikających z zaburzeń wstecznych. Zmiany były nasilone zw łaszcza w nerce, co wyjaśnia zahamowanie erytropoezy w tym narządzie.

Mimo istnienia pewnej reakcji wyrównawczej działalność układu czerwonokrwinkowego była upośledzona i rokująca niepomyślnie o dalszym przebiegu ery tropoezy pstraga.

власов т.

СИСТЕМА КРАСНЫХ КРОВЯНЫХ ТЕЛЕЦ У РАДУЖНОИ ФОРЕЛИ SАLМО

GAIRDNERI RICH. ПРИ ПРОДОЛЖЕННОЙ ПОДОСТРОЙ ФЕНОЛЬНОЙ

ИНТОКСИКАЦИИ

$$
P \text { e } 3 \text { ю } \mathrm{M} \text { e }
$$

Исследовали систему красных кровяных телец у радужной форели (196 особей), подвергавшейся действию фенола ( 2 мг/дм ${ }^{3}, 2$ месяца).

Установили снижение $\mathrm{Ht}$, концентрации гемоглобина ( $\mathrm{Hb}$ ) в крови и СГЭ (МСH), а также снижение осмотического сопротивления эритроцитов при одновременном постоянном уровне: числа эритроцитов, их среднего объёма (MCV) и средней концентрации $\mathrm{Hb}$ в тельце (МСНC).

Количественный анализ клеток исследованной системы показал статистически существенный эритробластоз периферической крови, торможение эритропоэза на уровне проэритробластов в почке и непропорциональное увеличение доли базофильных эритробластов в селезёнке.

По клеткам системы красных кровяных телец установлено ряд морфологических и структурных изменений как результат патологических вырождений. Резкие изменения наблюдались особенно в почке, что подтверждает торможение эритропоэза в этом органе.

Не смотря на некоторую компенсационную реакцию, действие системы красных кровяных телец отличалось дефектностью что прогнозировало неблагоприятное дальнейтее поведение эритропоэза у форели.

Author's address:

Received: 15 January, 1984

Dr. Teresa Własow

Akademia Rolniczo-Techniczna

Katedra Rybactwa

Kortowo

10-957 OLSZTYN

Polska (Poland) 